\title{
Deep dermal fibroblasts contribute to hypertrophic scarring
}

\author{
JianFei Wang ${ }^{1}$, Carole Dodd ${ }^{2}$, Heather A Shankowsky ${ }^{1}$, Paul G Scott ${ }^{2}$ and Edward E Tredget ${ }^{1,3}$, Wound Healing \\ Research Group
}

Hypertrophic scar (HTS) following thermal injury is a dermal fibroproliferative disorder that leads to considerable morbidity. The development of HTS involves numerous cell types and cytokines with dermal fibroblasts being a key cell. We have previously reported that the phenotype of fibroblasts isolated from HTS was altered compared to fibroblasts from normal skin. In this study, normal skin was horizontally sectioned into five layers using a dermatome from which fibroblasts were isolated and cultured. Cells from the deeper layers were observed to proliferate at a slow rate, but were morphologically larger. In ELISA and FACS assays, cells from the deeper layers produced more TGF- $\beta 1$ and TGF- $\beta 1$ producing cells were higher. In quantitative RT-PCR, the cells from the deeper layers had higher CTGF and HSP47 mRNA levels compared to those from superficial layers. In western blot, FACS and collagen gel assays, fibroblasts from the deeper layers produced more $\alpha$-smooth muscle actin ( $\alpha$-SMA), had higher $\alpha$-SMA positive cells and contracted collagen gels more. Fibroblasts from the deeper layers were also found to produce more collagen, but less collagenase by mass spectrometry and collagenase assay. Interestingly, cells from the deeper layers also produced more of the proteoglycan, versican, but less decorin. Taken together, these data strongly demonstrate that fibroblasts from the deeper layers of the dermis resemble HTS fibroblasts, suggesting that the deeper layer fibroblasts may be critical in the formation of HTS. Laboratory Investigation (2008) 88, 1278-1290; doi:10.1038/labinvest.2008.101; published online 27 October 2008

KEYWORDS: collagen; dermal depth; fibroblast; HTS; proteoglycan; TGF- $\beta 1$

Hypertrophic scarring is a common fibroproliferative disorder of the human dermis characterized by erythematous, raised, pruritic lesions of the healing skin, which is usually following thermal and other injuries that involve the deep dermis. ${ }^{1}$ These lesions lead to scarring that compromises the appearance of healing skin and are commonly associated with contractures that limit movement and function of involved joints and facial features. As such, HTS is the principal factor that contributes to the prolonged and often uncomfortable rehabilitation period for thermally injured patients, particularly those who have survived large lifethreatening injuries, children, and individuals of dark-skinned races, in whom such scarring occurs more commonly. ${ }^{2}$ The undesirable physical properties of HTS tissue can be attributed to the presence of a large amount of extracellular matrix that is of altered composition and organization, compared to normal dermis or mature scar. This matrix is the product of a dense population of fibroblasts, maintained in a hyperactive state by inflammatory cytokines such as TGF- $\beta$ and other factors, some of which may be physical in origin. ${ }^{3}$ Although the molecular and cellular events that lead to HTS have been extensively studied, the pathogenesis of this condition is still not well understood, making treatment difficult.

Key cells involved in HTS are the dermal fibroblasts. Dermal fibroblasts are a dynamic and diverse population of cells whose function in skin and HTS in many respects remain unknown. ${ }^{4}$ Normal adult human skin contains at least three distinct subpopulations of fibroblasts, which occupy unique niches in the dermis. Fibroblasts from each of these niches exhibit distinctive differences when cultured separately. ${ }^{5}$ Specific differences in fibroblast physiology are evident in papillary dermal fibroblasts, which reside in the superficial dermis, and reticular fibroblasts, which reside in the deep dermis. ${ }^{6}$ Another subpopulation of fibroblasts is associated with hair follicles ${ }^{7}$ and engages in fibroblast-epidermal

\footnotetext{
${ }^{1}$ Division of Plastic and Reconstructive Surgery, University of Alberta, Edmonton, Alberta, Canada; ${ }^{2}$ Department of Biochemistry, $2 \mathrm{D} 3.81$ WMSHC, University of Alberta, Edmonton, Alberta, Canada and ${ }^{3}$ Critical Care Medicine, 2D3.81 WMSHC, University of Alberta, Edmonton, Alberta, Canada Correspondence: Dr EE Tredget, MD, MSc, FRCSC, 2D3.81 WMSHC, 8440-112 Street, University of Alberta, Edmonton, Alberta, Canada, T6G 2 B7. E-mail: etredget@ualberta.ca 
interactions during hair development and in interfollicular regions of skin.

Studies have shown that dermal fibroblasts are an extremely heterogeneous multifunctional cell population and play an important regulatory role in wound healing. Fibroblasts cultured from the papillary and reticular dermis have different characteristics including difference in their proliferation kinetics, rates at which they contract type I collagen lattices, production of the proteoglycans decorin and versican, and in their size and packing density in confluent cultures. ${ }^{5,8-10}$ Fibroblasts associated with hair follicles also show a distinctive characteristic such as different amounts of protein production and are different from the cells in the papillary and reticular dermis. ${ }^{711}$ Studies have demonstrated that dermal fibroblasts present even within the same tissue sample are heterogeneous and their microenvironmental localization might be one of the main reasons for fibroblast heterogeneity. ${ }^{12}$ Studies have also demonstrated that the superficial papillary dermis contains a heterogeneous population of fibroblasts, and propose that diverse subpopulations of fibroblasts are required to interact in both homeostatic and pathological situations in the skin. ${ }^{13}$

The association between scarring and depth of dermal injury is clinically recognized and is evident from lasers used to treat superficial vascular malformations and for facial resurfacing. ${ }^{14,15}$ The depth of the injury, as well as the site of the wound, dictate the outcome of wound appearance, where superficial burn will heal quickly without scar. In a porcine skin wound model, deep partial thickness dermal burn resulted in HTS. ${ }^{16}$ Dunkin et al ${ }^{17}$ quantified the association between scarring and the depth of dermal injury in human volunteers using a novel jigsaw scratch/incision approach, where they found that there is a threshold depth of dermal injury at which scarring develops. These studies imply that deeper dermal fibroblasts may play a critical role in HTS.

Based on the significance of fibroblasts in HTS, we hypothesize that dermal fibroblasts are highly heterogeneous and deep dermal fibroblasts may play a critical role in HTS. Using dermatome separation, we isolated and cultured different layers of skin fibroblasts. We observed that dermal fibroblasts from deeper layers were morphological larger than those of the superficial layers; they proliferated slower; they produced less collagenase but more collagen, and they produced less decorin but more versican. Moreover, cells from the deeper layers produced more TGF- $\beta 1$ and $\alpha$-SMA compared to cells from more superficial layers. This data indicates that the phenotype of dermal fibroblasts from the deeper layers resemble those from HTS and strongly suggests that deep dermal fibroblasts may play a critical role in HTS.

\section{MATERIALS AND METHODS}

Protocols for human tissue sampling have been approved by the University of Alberta Hospitals, Health Research Ethics Board. Three normal tissue samples were obtained from patients who underwent elective surgery. A dermatome
Table 1 Source of human hypertrophic scar and normal fibroblasts

\begin{tabular}{|c|c|c|c|c|c|}
\hline Patient & Age (years) & Sex & TBSA (\%) & Months & Site of biop \\
\hline \multicolumn{6}{|c|}{ Group 1 (normal patients) } \\
\hline 1 & 38 & $\mathrm{~F}$ & NA & NA & Breast \\
\hline 2 & 45 & $\mathrm{~F}$ & NA & NA & Abdomen \\
\hline 3 & 49 & $\mathrm{~F}$ & NA & NA & Abdomen \\
\hline
\end{tabular}

Group 2 (burn patients)

$\begin{array}{rrrrrl}1 & 18 & \text { M } & 80 & 8 & \text { Hand } \\ 2 & 28 & \text { F } & 14 & 15 & \text { Chest } \\ 3 & 4 & \text { M } & 25 & 5 & \text { Hand } \\ 4 & 4 & \text { M } & 22 & 11 & \text { Shoulder }\end{array}$

F, female; $\mathrm{M}$, male; NA, not available; TBSA, total burn surface area.

(Padgett Instruments, Plainsboro, NJ, USA) was then set at approximately $0.5 \mathrm{~mm}$ to horizontally section these skin samples into five layers (layers 1-5 correspond to the upper to deeper layers, respectively) after the epidermal layer was discarded. Each layer was then cultured individually, as were the whole skin samples. Cultures of fibroblasts were established as previously described. ${ }^{18}$ The tissue and fibroblasts from HTS scar were collected from thermal injured patients who were treated at the University of Alberta Hospital Firefighters' Burn Treatment Unit. Following informed consent, eight tissue samples, four HTS and four normal skin specimens, were obtained from patients recovering from thermal injury who developed clinical evidence of hyperemic, raised, thickened, pruritic and noncompliant scars confined to the site of injury (Table 1). To control for the effects of factors such as sex, age, size of burn injury, infection, and variability in the individual scarring response such as the onset, duration, rate of resolution of HTS from one individual to another, ${ }^{19}$ we used site-matched normal skin from the same patients as a control. Strains of dermal fibroblasts at passages 3-8 were used in this study.

\section{Cell Size Measurement}

Diameters of fibroblasts released from confluent cultures were measured in triplicate by a coulter counter model ZM (Coulter Electronics of Canada Ltd, Quebec) calibrating with $22 \mu \mathrm{m}$ latex beads (Polysciences Inc.) at passages 3 or 4 . Micrographs of cells were also taken.

\section{Proliferation Assays}

\section{Coulter counter assay}

Cells were seeded at 10000 cells per well in 24-well plates and cultured for 25 days. Cells in triplicate wells were trypsinized and counted by coulter counter in every other day. 


\section{$\left[{ }^{3} \mathrm{H}\right]$-Thymidine incorporation assay}

To determine the proliferation rate of dermal fibroblasts from different layers, cells were seeded onto 24 -well plates at a concentration of $2.5 \times 10^{4}$ cells per well in the presence of DMEM supplemented with $10 \%$ FBS. Cells were grown to subconfluence for $24 \mathrm{~h}$, washed twice with PBS and grown in $2 \%$ FBS DMEM for an additional $24 \mathrm{~h}$. $\left[{ }^{3} \mathrm{H}\right]$-thymidine was then added for an additional $4 \mathrm{~h}$ at a concentration of $0.5 \mu \mathrm{Ci}$ per well. Cells were washed twice with PBS, dissolved with $4 \mathrm{M}$ GITC solution and $\left[{ }^{3} \mathrm{H}\right]$-thymidine was measured using a $\beta$-counter (LKB 1211 Rackbeta). ${ }^{20}$

\section{Analysis for collagenase activity}

This assay was carried out as previously described with slight modifications. ${ }^{21}$ Triplicate fibroblasts from different layers from different donors were used for this experiment. In brief, cells were grown to about 70\% confluency in DMEM/10\% FBS and washed, and then the medium was changed to $0.2 \%$ FBS DMEM. After 3 days, the media was collected, proteins in the conditioned medium were precipitated by ammonium sulfate and the precipitates were collected by centrifugation, dissolved in assay buffer $(50 \mathrm{mM}$ Tris, $200 \mathrm{mM} \mathrm{NaCl}, 5 \mathrm{mM}$ $\mathrm{CaCl}, 0.02 \%$ sodium azide, $\mathrm{pH} 7.4$ ) and then dialyzed overnight against 4 liter of the same buffer. The final volume of each sample was adjusted to the same number of cells. The latent procollagenase was activated proteolytically with trypsin $(10 \mathrm{mg} / \mathrm{ml}$; Worthington Biochemical Co., Freehold, NJ, USA), and soybean trypsin inhibitor $(100 \mathrm{mg} / \mathrm{ml}$, Sigma Chemical Co., St Louis, MO, USA) was used to inactivate the trypsin. Acetic acid soluble collagen $(2 \mathrm{mg} / \mathrm{ml})$ from bovine skin was incubated with the activated enzyme solution $(5 \mathrm{ml}$ for normal cells) in the presence of $6 \mathrm{M}$ glucose for 15-24 h. The products from digested collagen were then separated by electrophoresis with the use of $5 \%$ acrylamide gel containing SDS. The gel was stained with commassie blue, and the $\alpha(3 / 4)$ and $\alpha 2(3 / 4)$ products were quantified using a computerized scanner (Color One Scanner; Apple Inc., NY, USA) and imaging program (NIH Image Program, Bethesda, MD, USA).

\section{Western Blot}

To analyze decorin expression in dermal fibroblasts, cells were grown to confluency in DMEM/10\% FBS, the medium changed to DMEM/0.2\% FBS. After three days, the medium was collected from the flasks and applied to a $1 \mathrm{ml}$ column of DEAE-Sephacel equilibrated in $0.2 \mathrm{M} \mathrm{NaCl} / \mathrm{PBS}$. After washing with buffer, bound fractions were eluted with $1 \mathrm{M}$ $\mathrm{NaCl} / \mathrm{PBS}$, desalted in $15 \mathrm{ml}$ Millipore concentrators (MWCO 10K) and lyophilized. Samples were aliquoted and stored at $-80^{\circ} \mathrm{C}$. To analyze the expression of $\alpha$-SMA expression in dermal fibroblasts, cells were grown to confluency. Total protein from the cells was extracted with $2 \mathrm{ml}$ extraction buffer (8.9 M urea, 4\% CHAPS, $65 \mathrm{mM}$ DTT, $2 \%$ ampholytes, $0.23 \mathrm{mM}$ butylated hydroxytoluene and $1 \mathrm{mM}$ PMSF). The supernatant was concentrated in $15 \mathrm{ml}$ Millipore filter concentrator (MWCO 10K) to $500 \mu \mathrm{l}$, aliquoted into small volumes and stored at $-80^{\circ} \mathrm{C}$. Protein concentration of samples was measured by a Bradford protein assay. Equal amounts of solubilized protein from each cell layer were electrophoresed in $10 \%$ of SDS-polyacrylamide gels in $0.1 \mathrm{M}$ Tris borate/SDS buffer. One gel was stained with Coomassie blue to ensure protein quantities in each sample were comparable. The proteins in the other gels were transferred to PVDF membranes. The membranes were incubated with mouse antibodies for anti $\alpha$-SMA (DakoCytomation) or antidecorin (self-made) followed by a goat anti-mouse horseradish peroxidase-conjugated antibody (BioRad Hercules, CA, USA). Antibody binding was visualized with an enhanced chemiluminescence detection system according to the manufacturer's protocol (PerkinElmer Life Sciences, Boston, MA, USA). The blots were scanned in Adobe Photoshop and the bands digitized and quantified using UNSCAN-IT software (Silk Scientific Inc., Orem, UT, USA).

\section{Northern Analysis}

Fibroblasts were harvested and lysed with $500 \mu \mathrm{l}$ of $4 \mathrm{M}$ guanidium isothiocyanate (GITC) and the total RNA from fibroblasts was isolated by $\mathrm{GITC} / \mathrm{CsCl}$ procedure as described by Ghahary et al. ${ }^{22}$ Total RNA from each individual fibroblast culture was then separated by electrophoresis ( $10 \mu \mathrm{g}$ per lane) on a $1 \%$ agarose gel containing $2.2 \mathrm{M}$ formaldehyde then blotted onto nitrocellulose membrane. To control the RNA loading, quantities of $18 \mathrm{~S}$ ribosomal RNA were compared visually by ethidium bromide fluorescence. Northern blot analysis was done as previously described. ${ }^{23}$ Quantitative analysis of mRNA expression was accomplished by densitometry of mRNA bands using Scion Image Software Version 4.0.3 (Scion Corporation, Frederick, MD, USA).

\section{Enzyme-Linked Immunosorbent Assay for TGF- $\beta 1$}

Levels of TGF- $\beta 1$ produced by fibroblasts and from different dermal layers of skin were determined by an ELISA. ${ }^{24}$ For TGF- $\beta 1$ in condition media, fibroblasts from each layer were grown to confluency, the medium changed to $0.2 \%$ FBS DMEM and continued to culture for 2 additional days. An aliquot of $500 \mu \mathrm{l}$ was activated with $100 \mu \mathrm{l}$ of $1 \mathrm{~N} \mathrm{HCl}$ for $10 \mathrm{~min}$ and neutralized with $100 \mu \mathrm{l}$ of $1.2 \mathrm{~N} \mathrm{NaOH} / 0.5 \mathrm{M}$ HEPES. For TGF- $\beta 1$ in tissue homogenate, samples of wounded skin were homogenized using a Mikro-Dismembrator (B.Braun Biotech International, Allentown, PA, USA) in $600 \mu \mathrm{l}$ of lysis buffer ( $10 \mathrm{mmol} / \mathrm{l} \mathrm{PBS}, 0.1 \%$ sodium dodecyl sulfate, $1 \%$ Nonidet P- $40,5 \mathrm{mmol} / \mathrm{l}$ ethylenediaminetetraacetic acid; (EDTA)) containing complete protease inhibitor mixture (Sigma, Oakville, ON, Canada) to extract the proteins. The homogenates were centrifuged at 15000 r.p.m. for $15 \mathrm{~min}$ at $4^{\circ} \mathrm{C}$ to remove the debris. Tripicate samples of $200 \mu \mathrm{l}$ were added to an ELISA plate coated with TGF- $\beta$ SR of Quantikine Human TGF- $\beta 1$ Immunoassay kit (R\&D System, MI, USA) following the manufacture's instructions. Recombinant human TGF- $\beta 1$ (R\&D System) 
was used as the standard and TGF- $\beta 1$ levels were normalized for 1000 cells for fibroblasts.

\section{FACS Analysis for TGF- $\beta 1, \alpha$-SMA, Decorin and Versican Expression}

Cells from each cell layer were grown in 10\% FBS DMEM to $\sim 70 \%$ confluency, and then treated with $2 \mu \mathrm{g} / \mathrm{ml}$ Brefeldin A (Sigma, Oakville, ON, Canada) for $24 \mathrm{~h}$. The cells were harvested and fixed using $4 \%$ paraformaldehyde and permeabilized with $0.1 \%$ saponin in PBS. For TGF- $\beta 1$ analysis, the cells were permeabilized with $70 \%$ ethanol. Permeabilized cells were then incubated with anti-TGF- $\beta 1$, anti- $\alpha$-SMA, anti-decorin or anti-versican antibodies (R\&D System) at a concentration of $1 \mu \mathrm{g} / \mathrm{ml}$ on ice for $30 \mathrm{~min}$. Cells were washed again and incubated with a goat anti-mouse IgG conjugated to FITC, after washing, fluorescence was measured by flow cytometry (FACScan ${ }^{\mathrm{TM}}$, Becton Dickinson). The level of FITC fluorescence was measured through the FL-1 channel equipped with a $488 \mathrm{~nm}$ filter ( $42 \mathrm{~nm}$ band pass) and data were acquired on 10000 FITC positive cells per sample with fluorescent signals at logarithmic gain. Data were analyzed with CellQuest ${ }^{\mathrm{TM}}$ software.

\section{Collagen Lattice Contraction}

Lattice cultures were performed in collagen matrices as previously described, with some modifications. ${ }^{25}$ Briefly, $2 \times 10^{5}$ fibroblasts were suspended in $1.882 \mathrm{ml}$ of soluble rat tail collagen type 1 (Sigma, Oakville, ON, Canada) solution containing $18 \mathrm{mM}$ acetic acid, $3 \times$ DMEM, 7\% FBS and $6 \mathrm{mM} \mathrm{NaOH}$ and dispensed onto $35 \mathrm{~mm}$ culture plates and allowed to polymerize for $30 \mathrm{~min}$ at $37^{\circ} \mathrm{C}$. Immediately after polymerization, gels were detached by gently shaking. Collagen contraction was calculated by measuring the lattice diameter daily.

\section{Hydroxyproline Determination}

Hydroxyproline in conditioned medium was determined as previously described with slight modification. ${ }^{26}$ Briefly, protein was precipitated from the conditioned media using acetonitrile. Sample was centrifuged at $4^{\circ} \mathrm{C}$ for $15 \mathrm{~min}$. The precipitate was hydrolyzed in $6 \mathrm{~N} \mathrm{HCl}$ solution at $110^{\circ} \mathrm{C}$ overnight. The $\mathrm{N}$-butyl ester derivative of hydroxyproline was prepared after drying the hydrolysate and addition of a known amount of $N$-methyl-proline. Liquid chromatography/mass spectrometry analysis was performed on an HP 1100 Liquid chromatography linked to a HP 1100 Mass Selective detector monitoring the ions 188 ( $N$-butyl ester of 4-hydroxyproline) and 186 ( $N$-butyl ester of $N$-methyl-proline). Each sample was run in triplicate and the results expressed as ng of 4-hydroxyproline per $10^{5}$ cells per $48 \mathrm{~h}$ obtained by reference to a standard curve of 4-hydroxyproline analyzed under the identical conditions.

\section{Immunohistochemical Analysis of $\alpha$-Smooth Muscle Actin}

Immunohistochemical analysis was performed as described previously. ${ }^{24}$ Briefly, cryosections $(8 \mu \mathrm{m})$ were cut, fixed in cold acetone and stained with a rabbit antibody for $\alpha$-SMA (NeoMarkers Inc., Fremont, CA, USA). The slides were then incubated with $2 \mu \mathrm{g} / \mathrm{ml}$ of rabbit anti-mouse $\alpha$-SMA antibody at $4^{\circ} \mathrm{C}$ overnight. After washing, the slides were incubated with a goat anti-rabbit antibody conjugated with HRP (Sigma Aldrich, Oakville, ON, Canada). The signals on the tissues were revealed using a DAB with hydrogen peroxide. Thereafter, counterstaining was performed with hematoxylin. The slides were mounted and photographs were taken.

\section{Real-Time Reverse Transcription-Polymerase Chain Reaction}

Total RNA was extracted from the fibroblasts from different dermal layers of fresh tissue using $\mathrm{RNeasy}^{\mathrm{TM}}$ spin columns (Qiagen, Mississauga, ON, Canada) according to the manufacturer's recommendations. To eliminate contamination with genomic DNA, DNAse digestion was performed for $60 \mathrm{~min}$. First-strand cDNA was synthesized using an enhanced avian first strand synthesis kit (Sigma, Oakville, ON) at $42^{\circ} \mathrm{C}$ using $05 \mu \mathrm{g}$ total RNA extract. Real-time reverse transcription-polymerase chain reaction (RT-PCR) was conducted using Power SYBR ${ }^{\circledR}$ Green PCR Master Mix (ABI, Foster, CA, USA) in a $25 \mu$ l of tube with a total reaction volume of $25 \mu \mathrm{l}$ containing $1 \mu \mathrm{l}$ of a 1:2 dilution of firststrand reaction product, $0.4 \mu \mathrm{M}$ gene specific upstream and downstream primers. Amplification and analysis of cDNA fragments were carried out using a 7300 real-time PCR system (ABI). Cycling conditions were initial denaturation at $95^{\circ} \mathrm{C}$ for $3 \mathrm{~min}$, followed by 40 cycles consisting of a $15-\mathrm{s}$ denaturation interval at $95^{\circ} \mathrm{C}$ and a $30 \mathrm{~s}$ interval for annealing and primer extension at $60^{\circ} \mathrm{C}$. Amplification of the housekeeping gene hypoxanthine-guanine-phosphoribosyltransferase (HPRT) mRNA, which served as a normalization standard, was carried out with HPRT primers (GACCAGT CAACAGGGGACA, sense) and (ACACTTCGTGGGGTCC TTTT, antisense). The gene specific primers for CTGF were GAGTGTGCACTGCCAAAGAT (sense) and GGCAAGTGCA TTGGTATTTG (anti-sense). The gene specific primers for HSP47 were TGAAGATCTGGATGGGGAAG (sense) and CT TGTCAATGGCCTCAGTCA (anti-sense). Levels of mRNA were measured as CT threshold levels and normalized with the individual HPRT control CT values. Altered mRNA levels in cells are indicated as a 'fold change' compared with layer 1 cells or dermal layer 1 .

CTGF mRNA levels were also assessed by real-time RTPCR of dermal fibroblasts from layers 1 and 5 treated with $10 \mu \mathrm{g} / \mathrm{ml}$ of chicken anti-human TGF- $\beta 1$ neutralizing antibody (R\&D System) and isotype. 


\section{Statistical Analysis}

Experiments were carried out in triplicate or quadruplicate. Data are expressed as mean \pm s.e.m. Statistical analysis was performed using ANOVA with post hoc testing and Excel 7 with significance set at $P<0.05$.

\section{RESULTS}

\section{Cell Size at Confluence Increases with Depth of Dermal Origin}

To characterize the morphology of fibroblasts from different depths of skin, cell size was measured at confluency. Cells from the various layers showed a gradual increase in size as one descended in the dermis (Figure 1a) which was confirmed by micrographs that cells from layer 5 (Figure $1 \mathrm{~b}$ ) were larger than those from layer 1 (Figure 1c). Interestingly, when compared cells from HTS were compared to sitematched normal skin from the same patients. Cells from HTS were larger than those from normal skin as shown in Figure 1d, and those cells from deeper layer are similar in size to the cells from HTS.

\section{Cells from Deep Dermis Proliferate Slower in Culture}

To examine if there is a difference in cell proliferation from different layers, identical cell numbers were seeded and cultured for $48 \mathrm{~h}$, and then trypsinized and counted. As shown in Figure 2a, the number of cells from deeper layers is progressively lower than that of superficial layers after $48 \mathrm{~h}$ of culture. To further examine cell growth in different layers, $2.5 \times 10^{4}$ cells from each layer of donor 2 were chosen for thymidine incorporation assay. As shown in Figure $2 \mathrm{~b},\left[{ }^{3} \mathrm{H}\right]-$ thymidine incorporation in cells from layers 1 to 5 significantly decreased (8874, 7293, 6358, 4709 and 3364 c.p.m. respectively) with increasing tissue depth, where significantly lower $(P<0.0002)$ incorporation of $\left[{ }^{3} \mathrm{H}\right]$-thymidine occurred in fibroblasts from layers 5 and 4 than layer $1(P<0.00001)$. This further confirms that cells from the deep dermis proliferate at a slower rate.

\section{Cells from Deep Dermis Produce more TGF- $\beta 1$}

TGF- $\beta 1$ is one of the most important profibrotic cytokines in wound healing and has been reported to be overexpressed in HTS tissue. ${ }^{20}$ An ELISA was used to measure TGF- $\beta 1$ pro- a

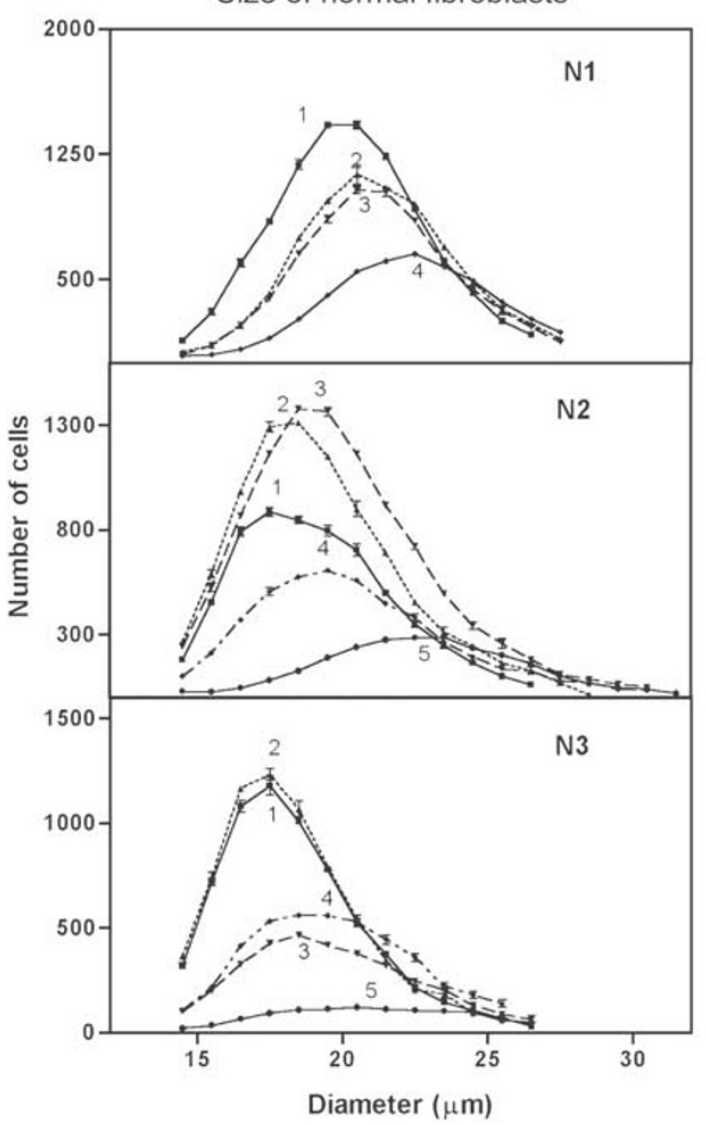

b
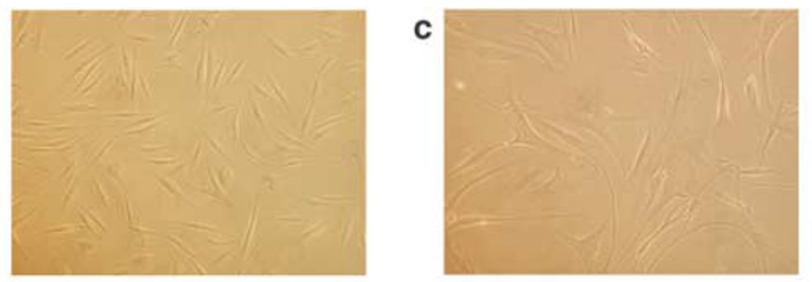

d
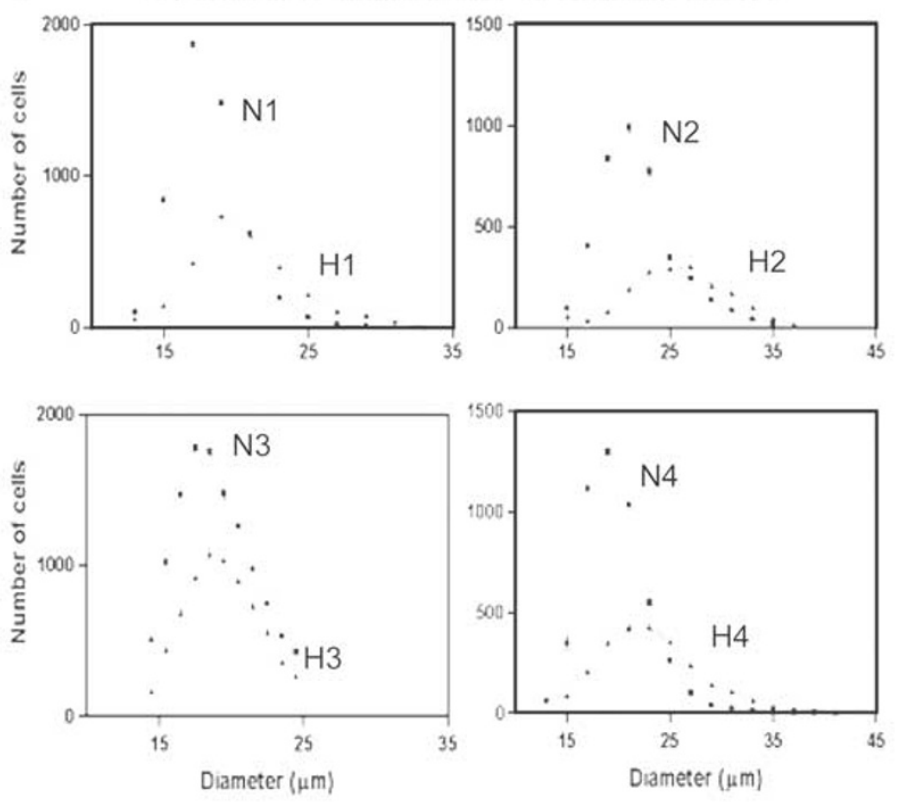

Figure 1 Size of dermal fibroblasts. Dermal fibroblasts from different layers of normal skin (a) were seeded at 10000 cells per well in 10\% FBS DMEM in 24well plates until confluency, and then cells were trypsinized and cell size was measured using a coulter counter in triplicate $(N=3)$. Dermal fibroblasts from layer 1 (b) and layer 5 (c) of normal skin were grown in 10\% FBS DMEM until 70\% of confluency, microphotographs were taken (bar $=100 \mu \mathrm{m}$ ). Size of paired fibroblasts from HTS $(N=4)$ were also measured $(d)$. 

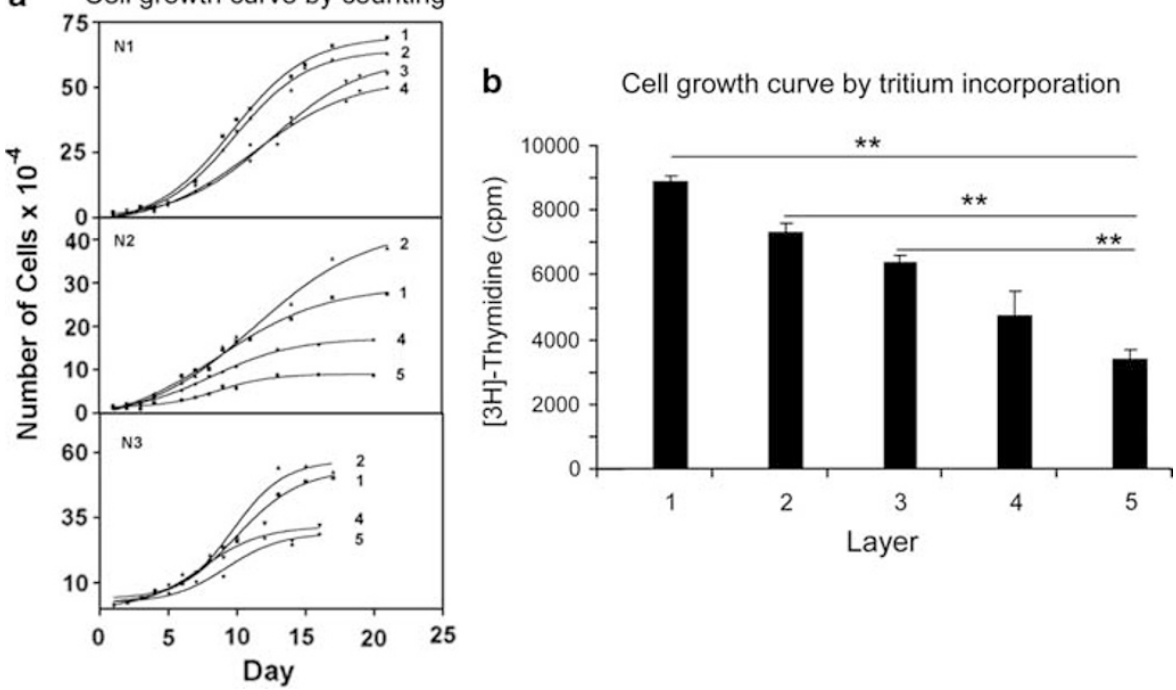

Figure 2 Proliferation of fibroblasts. (a) Measurement of cell proliferation using a coulter counter. Dermal fibroblasts from different layers of normal skin were seeded at 10000 cells per well in 10\% FBS DMEM in 24-well plates. At each time point cells were trypsinized and counted by Coulter Counter in triplicate $(N=3)$. (b) Measurement of cell proliferation by a $\left[{ }^{3} \mathrm{H}\right]$ thymidine incorporation assay. Dermal fibroblasts from different layers of donor 2 were seeded at 25000 cells per well in 10\% FBS DMEM in a 24 well plate overnight, then changed into DMEM/1\% FBS, cultured for $24 \mathrm{~h}$, and then pulsed with $\left[{ }^{3} \mathrm{H}\right]$ thymidine for $4 \mathrm{~h}$. The incorporation of $\left[{ }^{3} \mathrm{H}\right]$ thymidine was assessed. Data shown represent the mean \pm s.e. $\left({ }^{* * P}<0.001\right)$.

duction in cells from different layers. As shown in Figure 3a, TGF- $\beta 1$ production by fibroblasts significantly increased with increasing tissue depth. Moreover, TGF- $\beta 1$ levels in fresh tissue from the deep layers were significantly higher than superficial layers (Figure 3b). To further verify this observation, FACS analysis was also used. We took cell strains from all layers of donor 2 , labeled with an anti-TGF- $\beta 1$ antibody conjugated with phycoerythrin (PE), and then analyzed using flow cytometry. ${ }^{20}$ As shown in Figure 3c, TGF- $\beta$ positive cells from layer 1 to 4 are $8.0,13.6,28.8$ and $30.5 \%$, respectively. In contrast, as many as $72.7 \%$ of the fibroblasts from layer 5 (deepest layer) produce TGF- $\beta 1 \quad(P<0.001)$. This further confirms that a higher proportion of cells from the deep dermis produce TGF- $\beta$.

\section{Cells from Deep Dermis and Deep Dermal Tissues Have Upregulated CTGF mRNA which may Result in more TGF- $\beta 1$ Levels}

A downstream mediator induced by TGF- $\beta 1$ that plays an important role in regulating fibroblasts function is connective tissue growth factor (CTGF). ${ }^{27}$ CTGF has been reported to have an important role during wound healing by stimulating cell proliferation, adhesion, chemotaxis, angiogenesis and production of ECM. ${ }^{27}$ To determine mRNA levels for CTGF in fibroblasts from different layers, real-time PCR was performed and showed significantly higher mRNA levels for CTGF in the deepest cell layer compared to the most superficial cell layer (Figure 3d). As well, CTGF mRNA levels in fresh tissue from deep layer were significantly higher than the superficial layer (Figure 3e). However, when treated with a TGF- $\beta 1$ neutralizing antibody, mRNA levels for CTGF in cells from layer 5 were significantly downregulated (Figure 3d) indicating the difference in CTGF expression in fibroblasts from different layers may at least partially result from TGF- $\beta 1$.

\section{Cells from Deep Dermis Produce more Collagen and less Collagenase}

We have previously reported that there is an imbalance in collagenase and collagen production in HTS. ${ }^{28}$ In this study, we measured collagenase activity in cells from different layers. As shown in Figure 4a, collagenase activity decreased with increasing cell layer depth. To check collagen content, we took cells from layers 1 through 5 of donor 2 and measured hydroxyproline using mass spectrometry. Interestingly, as shown in Figure $4 \mathrm{~b}$, increasing amounts of hydroxyproline were produced by cells from increasingly deeper layers again suggesting that fibroblasts from the deepest layer more closely resemble HTS fibroblasts.

\section{Cells from Deep Dermis have Upregulated HSP47 mRNA}

HSP47 is a heat shock protein that is also reported to be a molecular chaperone for some types of collagen including type $1 .{ }^{29,30}$ mRNA levels for HSP47 in cells from different layers were assessed by a real-time PCR. Results in Figure 4c indicate a more than four fold increase in HSP47 expression in fibroblasts from the deepest dermal layer compared to the most superficial layer. 

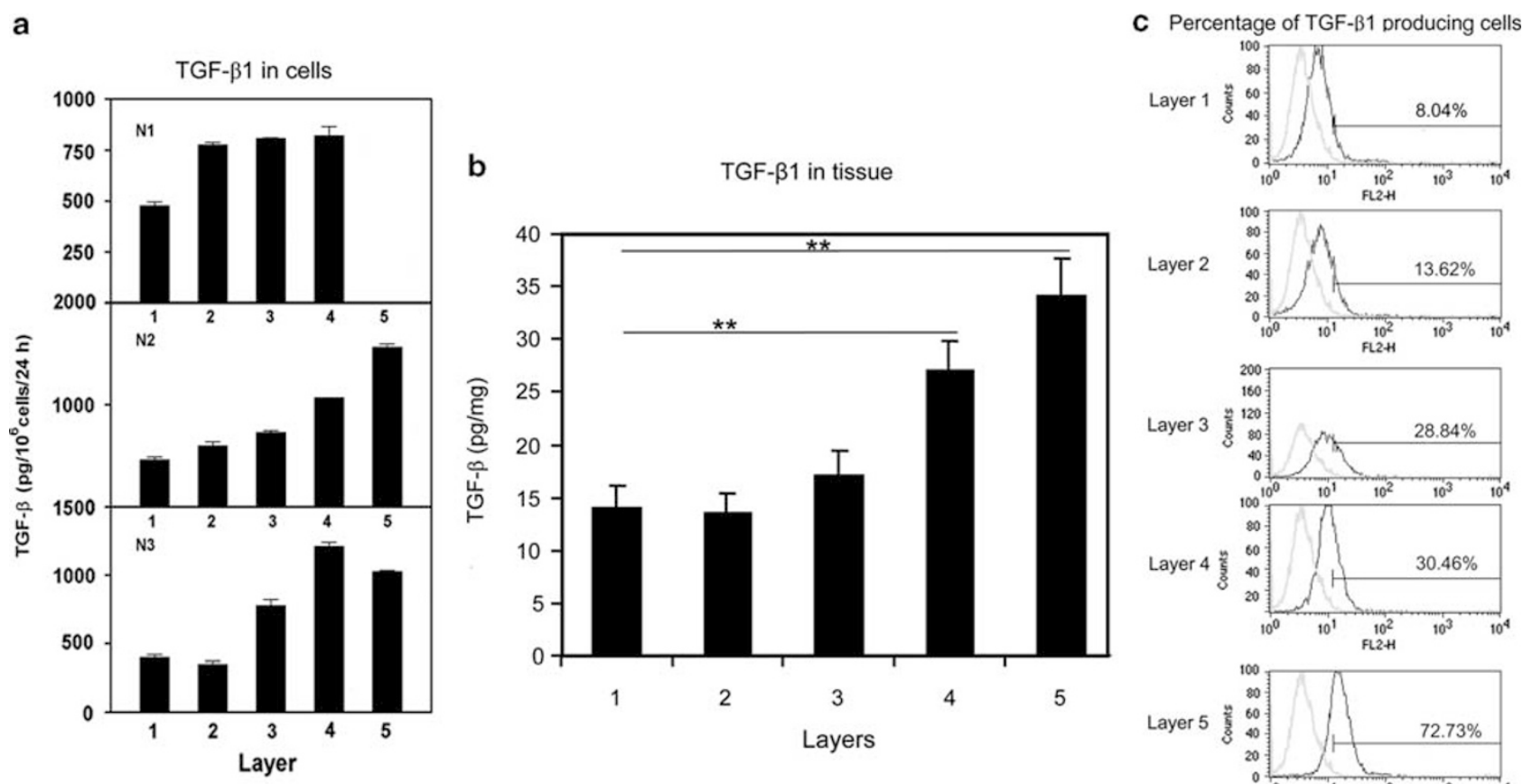

b

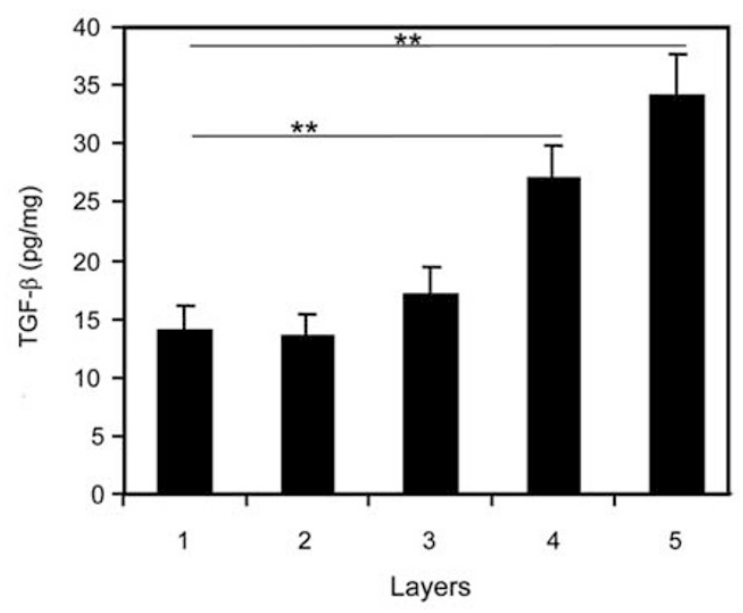

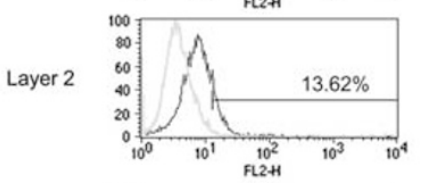
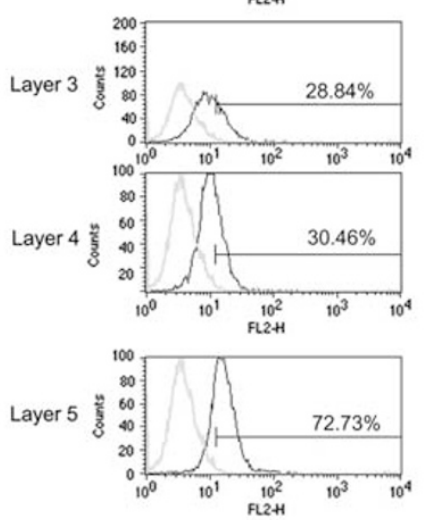

d

e CTGF mRNA in tissue

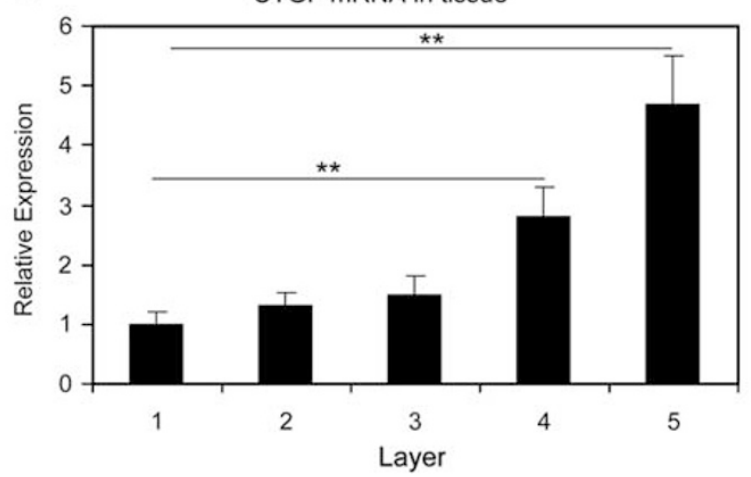

Figure 3 Dermal fibroblast TGF- $\beta 1$ and CTGF production. Levels of TGF- $\beta 1$ in dermal fibroblast conditioned medium (a) and different layers of tissue (b) were assessed by an ELISA assay. TGF- $\beta 1$-producing cells were measured by FACS (c). Dermal fibroblasts from different layers were seeded and serum starved, then treated with a TGF- $\beta 1$ neutralizing antibody, the total RNA was extracted, and real-time PCR was performed to analyze CTGF mRNA expression (d). Total RNA was extracted from different layers of skin of donor 2, CTGF mRNA levels was assessed by real-time RT-PCR (e). Data are expressed as the mean \pm s.e. $(N=3)\left({ }^{* * P}<0.001\right)$.

\section{Cells from Deep Dermis Express more $\alpha$-SMA and Contract Collagen Lattice Gels}

An important part of wound healing is wound contraction and myofibroblasts are believed to play a crucial role in this process. ${ }^{31,32}$ Myofibroblasts are characterized by the expression of $\alpha$-SMA and are thought to be derived from the fibroblast population under profibrotic growth factor stimulation. ${ }^{33}$ When protein from the same number of dermal fibroblasts from different layers is analyzed for $\alpha$-SMA expression by western blot, a higher level of $\alpha$-SMA was detected in fibroblasts from the deeper layers (Figure 5a). To confirm this observation, fibroblasts from different layers of the dermis from donor 2 were subjected to $\alpha$-SMA expression analysis by FACS. As shown in Figure $5 b$, about $10 \%$ of $\alpha$-SMA positive cells were detected in layer 1 . The number of
$\alpha$-SMA positive cells increased with depth, such that $25 \%$ of fibroblasts were $\alpha$-SMA positive in layer 5 . Immunohistochemistry analysis demonstrated that the deep dermis has enhanced $\alpha$-SMA staining compared to the superficial dermis (Figure 5e). To determine whether these cells were functional and could contribute to wound contraction, fibroblasts from layer 1 and 5 were seeded in collagen lattices and contraction was measured for $72 \mathrm{~h}$. As shown in Figure $5 \mathrm{c}$, lattices populated with fibroblasts from layer 1 showed $48 \pm 7.0 \%, 68 \pm 5.8 \%$ and $79 \pm 8.4 \%$ contraction over 24,48 and $72 \mathrm{~h}$ respectively. A significant increase $(P<0.003)$ in contraction was observed at time points for cells from layer 5: they were $63 \pm 7.6 \%, 81 \pm 6.0 \%$ and $91 \pm 6.8 \%$ respectively. Figure $5 \mathrm{~d}$ shows a significant increase in $\alpha$-SMA expression in fibroblasts from HTS compared to normal skin tissue in the 
a

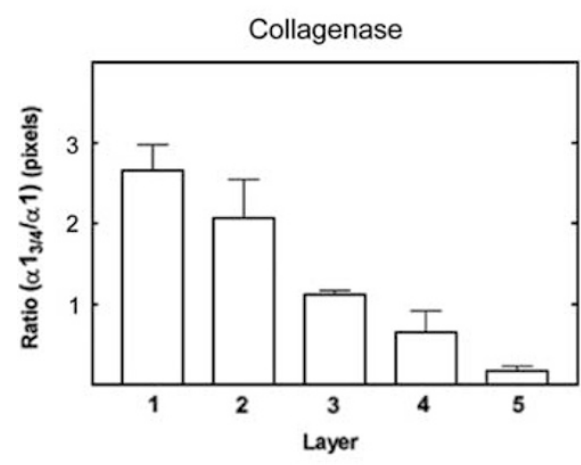

b

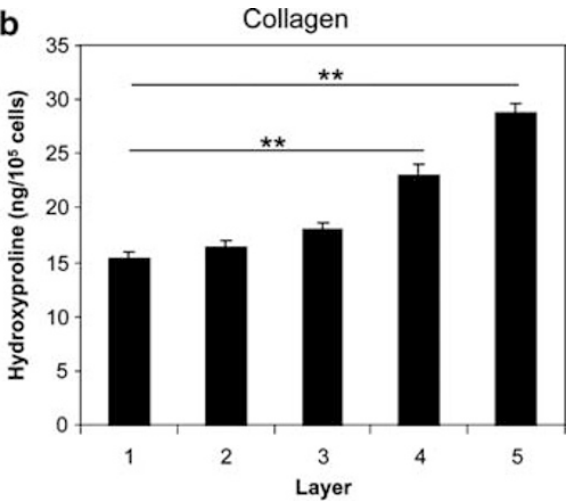

C $\quad$ HSP47 mRNA

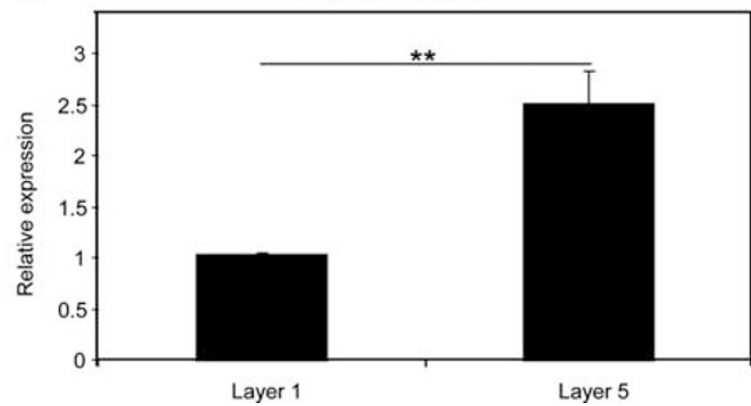

Figure 4 Collagenase and collagen content measurement in dermal fibroblasts. (a) Collagenase activity in dermal fibroblasts. Dermal fibroblasts from different layers were grown to about 70\% confluency in DMEM/10\% FBS and washed. They were then changed to DMEM/0.2\% FBS. After 3 days, the media was collected and collagenase activity was measured as described in the Materials and Methods section. (b) Collagen content in dermal fibroblasts. Dermal fibroblasts from different layers were grown to about $70 \%$ confluency in DMEM/10\% FBS, washed, and then changed to DMEM/0.2\% FBS. After 3 days, the media was collected and hydroxyproline analysis was assessed by a mass spectrometry. (c) Dermal fibroblasts from different layers were seeded, serum starved, the total RNA was extracted, and real-time PCR was performed to analyze HSP47 mRNA expression. Data are expressed as the mean \pm s.e. $(N=3)$ $(* * P<0.001)$.

same patients. This data indicates that deep dermal fibroblasts more closely resemble fibroblasts in HTS in terms of $\alpha$-SMA expression than superficial layer fibroblasts.

\section{Cells from Deep Dermis make Less Decorin}

Decorin is small proteoglycan involved in collagen fiber organization in dermis and has been reported to play a role in modulating the in vivo activity of fibrogenic cytokines such as TGF- $\beta 1 .^{34}$ Fibroblasts from HTS have been shown to produce less decorin. ${ }^{34}$ We first analyzed decorin expression in conditioned media in cells from different dermal layers by ELISA (Figure 6a) and then assessed decorin gene expression in cells from different dermal layers by northern blot (Figure 6b). As it is has been shown that decorin expression by fibroblasts from the deeper layers in two donors was significantly lower than that by fibroblasts from the superficial layers; FACS analysis (Figure 6c) demonstrated that fibroblasts from superficial layers were able to produce decorin ( $\sim 98.7 \%)$, but decorin production gradually decreased with increasing dermal depth, only about $75 \%$ of cells from layer 5 expressed decorin. This further suggests that reduced decorin expression in occurs in fibroblast of deep dermal layers, another feature shared with HTS fibroblasts.

\section{Cells from Deep Layer Generate more Versican}

Versican is a large proteoglycan, known to promote a variety of functions in cells including adhesion, migration and proliferation. ${ }^{35}$ Versican can also enhance attachment of hyaluronic acid to cell membranes, ${ }^{36}$ between glycosaminoglycans and versican ligands (eg collagen I, fibronectin, etc), and between the ECM and cell surface glycoproteins (ie cell recognition). In a porcine wound healing model, mRNA levels for versican were observed to be upregulated. ${ }^{37}$ We examined versican expression by flow cytometry. As shown in Figure 7, 19\% of fibroblasts from superficial layers are versican positive cells; versican expression increases with cell depth, whereas, in cells from the deepest layers of the dermis, versican expression increases to $82 \%$ of the total number of fibroblasts from layer 5 .

\section{DISCUSSION}

The development of HTS involves a complex interplay between cells and cytokines, as well as local and systemic factors exerted on dermal fibroblasts, resulting in a distinctive HTS fibroblast phenotype. Although the mechanism underlying its pathogenesis is not well understood, four factorsgenetics, epithelial and mesenchymal interaction, inflammation, and mechanic pressure-are suggested to account for 


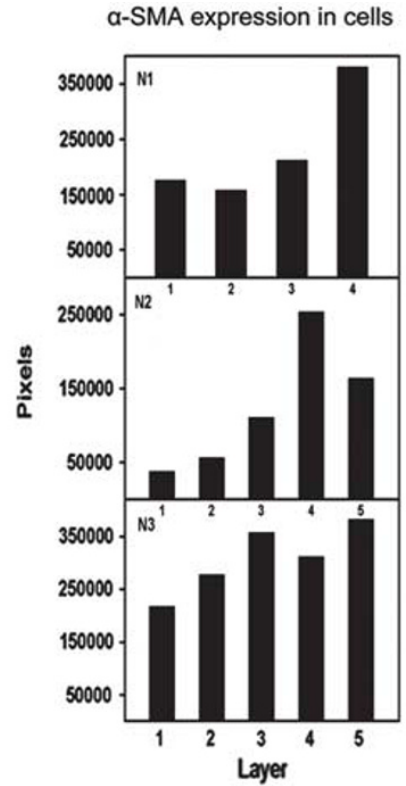

b Percentage of $\alpha$-SMA producing cells

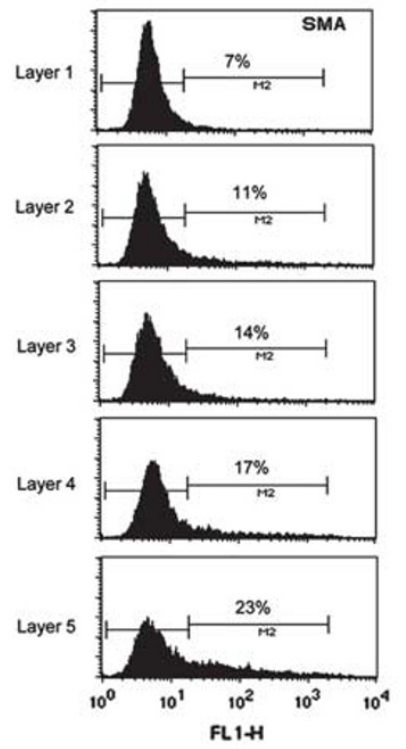

C

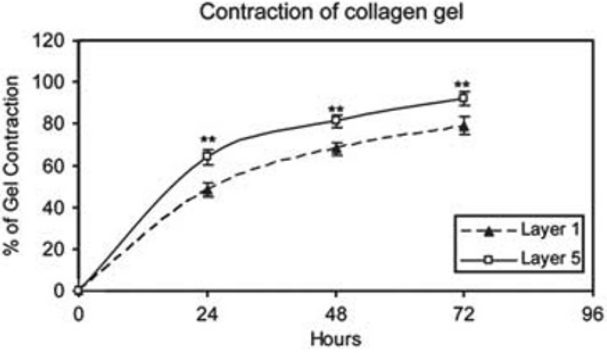

e

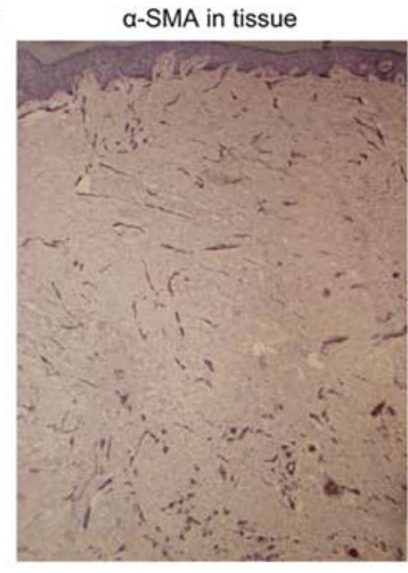

Figure $5 \alpha$-SMA in dermal fibroblasts and collagen lattice gel assay. Dermal fibroblasts from different layers of normal skin were grown to about $70 \%$ confluency in 10\% FBS DMEM, and washed, and then changed to DMEM/0.2\% FBS. After 3 days, the cells were collected for $\alpha$-SMA analysis by a western blot (a) and FACS (b). (c) Dermal fibroblasts from different layers of normal skin of were seeded in collagen lattices. The contraction assay was performed as described in the Material and Methods section $(N=3)$. (d) Comparison of $\alpha$-SMA expression in paired fibroblasts from normal skin (open bar) and corresponding HTS (closed bar) from the same donors by western blot $(N=4, * * P<0.001)$. (e) Immunohistochemistry analysis of $\alpha$-SMA expression in normal skin. Original magnifications: $\times 20 ; \mathrm{bar}=500 \mu \mathrm{m}$.

much of the altered phenotype of fibroblasts in HTS following thermal injury. ${ }^{38}$ Here we report that fibroblasts from different skin depths are significantly different from cells located at more superficial regions in dermis in terms of cell proliferation, size, TGF- $\beta 1$, collagen, collagenase, $\alpha$-SMA, decorin and versican production. Moreover, our data strongly suggests that the phenotype of deeper layer fibroblasts resembles that of HTS fibroblasts and that intrinsic properties of dermal fibroblasts from deep layers in the dermis may play a critical role in development of HTS after thermal injury.
The development of HTS is often linked to the overexpression of TGF- $\beta 1 .{ }^{20}$ Elevated levels of TGF- $\beta 1$ are found in the serum of recovering burn patients. ${ }^{20,39}$ and HTS stain more intensely for this cytokine than do normal skin samples or mature scars. ${ }^{40}$ TGF- $\beta 1$ is therefore a key cytokine in wound healing and hypertrophic scarring. ${ }^{2}$ TGF- $\beta 1$ is produced by all the major cell types participating in wound repair, including T-lymphocytes, macrophages, smooth muscle cells, endothelial cells, fibroblasts, epithelial cells and fibrocytes. ${ }^{41,42}$ Fibroblasts are the predominant cell type involved in healing wounds and may provide much of the 

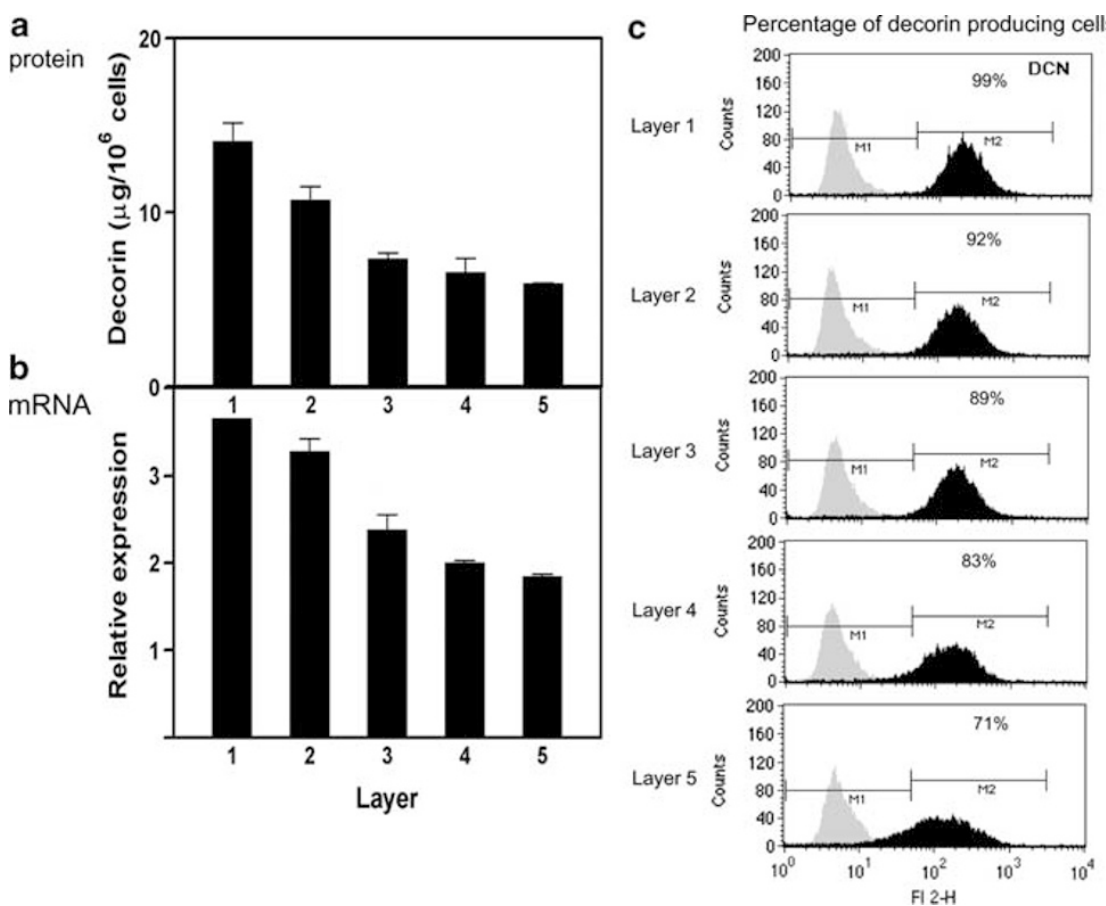

Figure 6 Decorin production in dermal fibroblasts. Dermal fibroblasts from different layers of 3 normal skin were grown to about $70 \%$ confluency in DMEM/ $10 \% \mathrm{FBS}$, and washed, and then changed into DMEM/0.2\% FBS. After 3 days, the cells were collected for decorin production assessed by western blot (a), northern blot (b) and FACS (c).

TGF- $\beta 1$ in an active HTS, especially as its synthesis can be auto-induced in these cells. ${ }^{43}$ We have previously reported that fibroblasts from HTS produce significant amount of TGF- $\beta$ protein compared to fibroblasts from paired normal fibroblasts. ${ }^{44}$ We show here that fibroblasts from deeper dermal layers progressively produce increasing amounts of TGF- $\beta 1$ compared to superficial layers. Moreover, a large proportion of TGF- $\beta 1$ producing fibroblasts are observed in the deeper layers of the dermis. This data suggests that fibroblasts from the deeper dermal layers resemble fibroblasts in HTS in terms of TGF- $\beta 1$ production and as such may contribute substantially to the cell population in HTS.

Previous studies have shown that TGF- $\beta 1$ and CTGF coordinately function together to regulate wound healing. ${ }^{45}$ CTGF exhibits numerous biological properties that are of potential importance in the wound healing response, including stimulation of cell proliferation, cell adhesion, chemotaxis, angiogenesis and production of ECM components. ${ }^{46,47}$ In addition, like TGF- $\beta 1$, CTGF has been linked to several fibrotic disorders. ${ }^{27}$ CTGF mRNA expression was reported to increase 20 fold in isolated fibroblasts from HTS compared to normal fibroblasts. When stimulated with TGF$\beta 1$, fibroblasts from HTS were seen to increase CTGF mRNA expression more than 150 fold compared with normal fibroblasts. ${ }^{48}$ In this study, we show that fibroblasts derived from the deeper dermis demonstrated a significantly increased CTGF mRNA levels compared to cells from superficial layers. This suggests that the fibroblasts from the deeper dermal layers resemble HTS cells in terms of CTGF production. In addition, mRNA levels for CTGF in TGF- $\beta 1$ neutralizing antibody treated deep dermal cells is significantly downregulated compared to IgG isotype-treated cells, suggesting a difference in CTGF expression in fibroblasts from different layers may at least partially result from TGF- $\beta 1$ and be secondary results.

Following skin injury, fibroblasts differentiate into contractile and secretory myofibroblasts that contribute to tissue repair during wound healing. ${ }^{32}$ However, in HTS, due to an increased number of myofibroblasts, contraction and ECM protein secretion become excessive, severely impairing skin function. ${ }^{32}$ Myofibroblasts are characterized by the expression of $\alpha$-SMA and are thought to be derived from the fibroblast population under stimulation by profibrotic growth factors such as TGF- $\beta 1 .^{49}$ In this study, using paired fibroblasts, we have shown an increase in $\alpha$-SMA expression in fibroblasts derived from HTS compared to cells from normal skin. Interestingly, fibroblasts derived from the deeper dermal layers produce more $\alpha$-SMA protein compared to cells from the superficial layers, consequently, the percentage of $\alpha$-SMA producing cells is higher in the deeper layers. When cells are incorporated in collagen lattice gel, fibroblasts from the deeper layers contract the lattice more than cells from the superficial layers. Taken together, this data strongly suggests that deep layer dermal fibroblasts resemble the phenotype of HTS fibroblasts in terms of $\alpha$-SMA expression. 


\section{Percentage of versican producing cells}
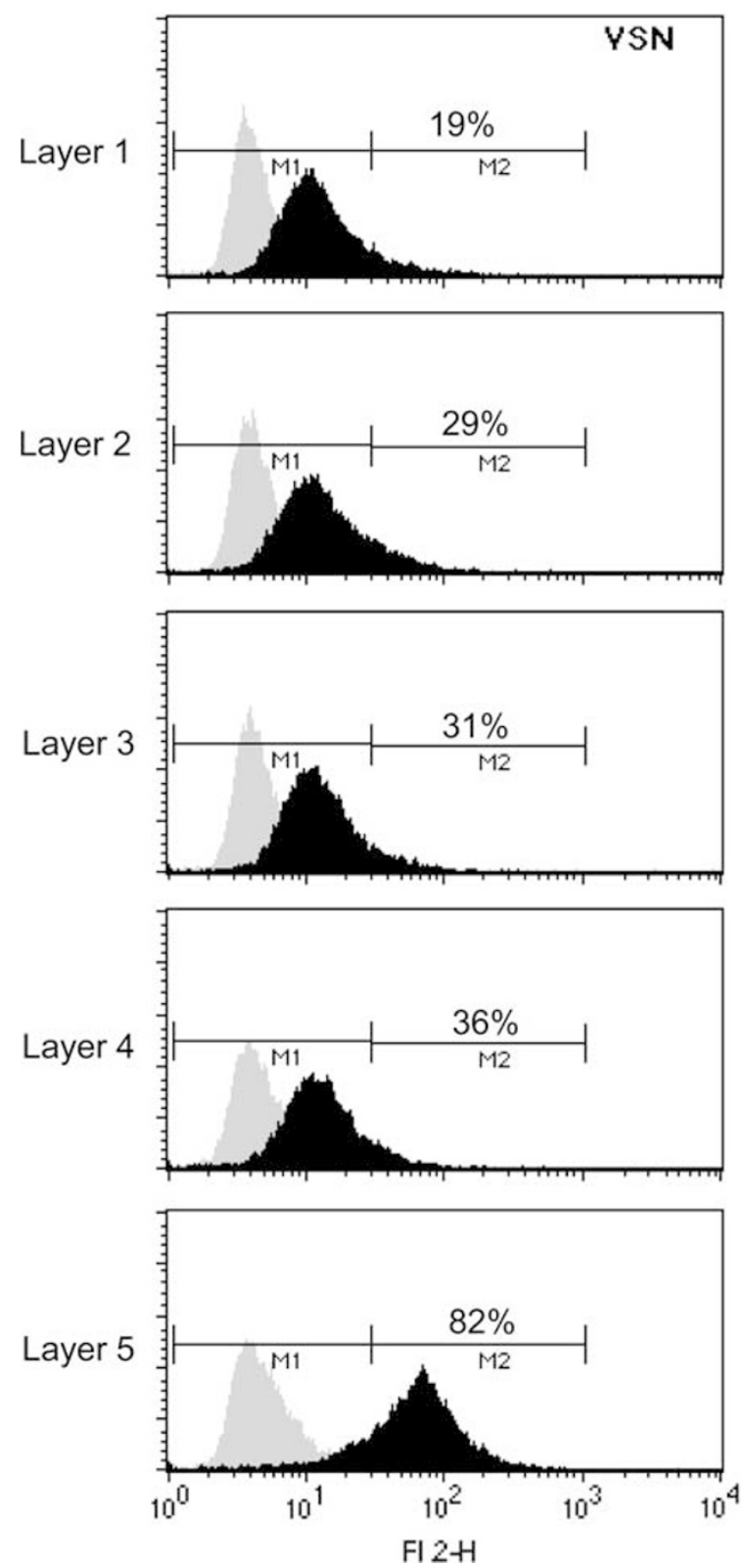

Figure 7 Versican production in dermal fibroblasts. Dermal fibroblasts from different layers of 3 normal skin were grown to about $70 \%$ confluency in DMEM $/ 10 \%$ FBS, and washed, and then changed to DMEM/0.2\% FBS. After 3 days, the cells were collected for versican production, which was measured by FACS. Figure is representative of three skins, which is from donor 2 .

Under physiological conditions, there is a balance between the synthesis and degradation of collagen in human dermal tissues. ${ }^{50}$ Extensive thermal injuries often disrupt this balance and lead to abnormalities in collagen metabolism, a characteristic feature of several forms of fibrotic conditions. ${ }^{51,52}$ HTS is characterized by increased collagen deposition. ${ }^{53}$ Thus, alteration in ECM composition is believed to be partially responsible for the undesirable physical properties of
HTS tissue. We previously reported evidence that HTS fibroblasts express much less collagenase mRNA than normal cells obtained from the same patients, but instead express more collagen types I and III mRNA. ${ }^{28}$ This differential synthesis of collagen and collagenase in HTS appears to be of an important feature which leads to excessive accumulation of collagen in this fibrotic condition. In this study, dermal fibroblasts from deeper layers were observed to produce more collagen but less collagenase, resembling the fibroblast phenotype from HTS. In addition, our results revealed that increased collagen production observed in deeper layer skin fibroblasts is accompanied by the upregulation of Hsp47 expression, a collagen chaprone. As Hsp47 plays an important role in collagen biosynthesis, ${ }^{29}$ this feature of fibroblasts from the deeper dermal layers is consistent with increased synthesis and altered assembly of collagen. Thus, in terms of ECM production, fibroblasts derived from deeper dermal layers produced more collagen and less collagenase than cells from superficial layers, which further suggests that fibroblasts from deep dermal layers resemble HTS fibroblast phenotype.

Proteoglycans influence physical properties of connective tissues and influence cellular activity. The morphology of collagen fibrils and their organization are profoundly affected by the nature and amounts of proteoglycans present in the connective tissue. ${ }^{3}$ In HTS after thermal injury, the content of proteoglycan has been reported to be altered as compared to normal skin. Decorin, a small dermatan sulfate proteoglycan decorin, is the major proteoglycan found in normal dermis. HTS contains on average only $25 \%$ of the amount of decorin found in normal dermis. It also contains six fold higher concentrations of the large proteoglycan, versican. ${ }^{54}$ Moreover, fibroblasts cultured from post-burn HTS contain less decorin mRNA and synthesize less of the protein than do normal fibroblasts. ${ }^{34}$ In this study, fibroblasts from the deeper dermal layers produce less decorin compared to cells from superficial regions and there is a decreasing percentage of decorin producing cells with increasing dermal depth. In contrast, higher percentages of versican producing cells were observed with increasing dermal depths. This again suggests that fibroblasts from the deeper dermal layers are more similar to HTS fibroblasts in terms of proteoglycan production than are superficial fibroblasts.

When fibroblasts receive stimulation in the injured tissue environment, cell spreading, nuclear extension, DNA synthesis and protein production will all increase cell size. Thus stimulated fibroblasts demonstrate increased size and slower rate of proliferation. Moreover, this increased size of fibroblasts is likely associated with the increased capacity of cells to synthesize ECM. In this study, we have compared the cell size of normal and HTS fibroblasts from the same patients and found that HTS fibroblasts are much larger than those from normal skin. Furthermore, cells from the deeper dermal layers demonstrate significant increase in size and decreased proliferation rate relative to superficial layers. This further 
suggests that the phenotype of cells from deeper dermal layer in terms of size and proliferation is similar to that of HTS fibroblasts.

Fibroblast heterogeneity has been very well documented over the last two decades with respect to a variety of parameters including differences in proliferation rates, ${ }^{55}$ responses to prostaglandins, ${ }^{56}$ collagen synthesis, ${ }^{57}$ cytokine production $^{58}$ and cytokine receptors. ${ }^{59}$ Phenotypic diversity also exists within fibroblast populations, along with differences in morphology ${ }^{60}$ and cell size. ${ }^{61,62}$ In this study, we have presented evidence that dermal fibroblasts from different depth of skin are highly heterogeneous and the deeper layer cells most closely resemble the HTS fibroblast phenotype. Further examination of dermal fibroblast heterogeneity in response to inflammatory stimulation will improve our understanding of the pathogenesis of abnormal hypertrophic scarring, and may eventually lead to novel treatments for this form of fibroproliferative disorder.

\section{ACKNOWLEDGEMENTS}

This work was supported by the Canadian Institutes of Health Research, the Alberta Heritage Foundation for Medical Research and the Firefighters' Burn Trust Fund of the University of Alberta. We thank Mr Takashi Iwashina for hydroxyproline measurements.

1. Scott PG, Ghahary A, Tredget EE. Molecular and cellular aspects of fibrosis following thermal injury. Hand Clin 2000;16:271-287.

2. Tredget EE. Pathophysiology and treatment of fibroproliferative disorders following thermal injury. Ann NY Acad Sci 1999;888:165-182.

3. Scott PG, Ghahary A, Wang JF, et al. Molecular and Cellular Hypertrophic Scarring. Saunders Elsevier Inc., Philadelphia, 2007, pp 596-607.

4. Sorrell JM, Caplan Al. Fibroblast heterogeneity: more than skin deep. J Cell Sci 2004;117:667-675.

5. Sorrell JM, Baber MA, Caplan Al. Site-matched papillary and reticular human dermal fibroblasts differ in their release of specific growth factors/cytokines and in their interaction with keratinocytes. J Cell Physiol 2004;200:134-145.

6. Bressler RS, Bressler $\mathrm{CH}$. Functional anatomy of the skin. Clin Podiatr Med Surg 1989:6:229-246.

7. Reynolds AJ, Jahoda CA. Inductive properties of hair follicle cells. Ann NY Acad Sci 1991;642:226-241; discussion 241-222.

8. Harper RA, Grove G. Human skin fibroblasts derived from papillary and reticular dermis: differences in growth potential in vitro. Science 1979;204:526-527.

9. Azzarone B, Macieira-Coelho A. Heterogeneity of the kinetics of proliferation within human skin fibroblastic cell populations. J Cell Sci 1982;57:177-187.

10. Schafer IA, Pandy M, Ferguson $R$, et al. Comparative observation of fibroblasts derived from the papillary and reticular dermis of infants and adults: growth kinetics, packing density at confluence and surface morphology. Mech Ageing Dev 1985;31:275-293.

11. Jahoda CA, Reynolds AJ. Dermal-epidermal interactions. Adult follicle-derived cell populations and hair growth. Dermatol Clin 1996:14:573-583.

12. Ali-Bahar $\mathrm{M}$, Bauer $\mathrm{B}$, Tredget $\mathrm{EE}$, et al. Dermal fibroblasts from different layers of human skin are heterogeneous in expression of collagenase and types I and III procollagen mRNA. Wound Repair Regen 2004;12:175-182.

13. Sorrell JM, Baber MA, Caplan Al. Clonal characterization of fibroblasts in the superficial layer of the adult human dermis. Cell Tissue Res 2007;327:499-510.

14. Ross EV, Naseef GS, McKinlay JR, et al. Comparison of carbon dioxide laser, erbium:YAG laser, dermabrasion, and dermatome: a study of thermal damage, wound contraction, and wound healing in a live pig model: implications for skin resurfacing. J Am Acad Dermatol 2000;42:92-105.

15. Seukeran DC, Collins P, Sheehan-Dare RA. Adverse reactions following pulsed tunable dye laser treatment of port wine stains in 701 patients. Br J Dermatol 1997;136:725-729.

16. Cuttle L, Kempf M, Phillips GE, et al. A porcine deep dermal partial thickness burn model with hypertrophic scarring. Burns 2006;32:806-820.

17. Dunkin CS, Pleat JM, Gillespie PH, et al. Scarring occurs at a critical depth of skin injury: precise measurement in a graduated dermal scratch in human volunteers. Plast Reconstr Surg 2007;119:1722-1732; discussion 1733-1724.

18. Ghahary A, Shen Q, Shen YJ, et al. Induction of transforming growth factor beta 1 by insulin-like growth factor-1 in dermal fibroblasts. J Cell Physiol 1998;174:301-309.

19. Ghahary A, Shen YJ, Nedelec B, et al. Enhanced expression of mRNA for insulin-like growth factor-1 in post-burn hypertrophic scar tissue and its fibrogenic role by dermal fibroblasts. Mol Cell Biochem 1995;148:25-32.

20. Wang J, Jiao H, Stewart TL, et al. Increased TGF-beta-producing CD4+ T lymphocytes in postburn patients and their potential interaction with dermal fibroblasts in hypertrophic scarring. Wound Repair Regen 2007;15:530-539.

21. Scott PG, Goldberg HA. Cleavage of the carboxy-terminal cross-linking region of type I collagen by proteolytic activity from cultured porcine gingival explants. Coll Relat Res 1983;3:295-304.

22. Ghahary A, Marcoux Y, Karimi-Busheri F, et al. Differentiated keratinocyte-releasable stratifin (14-3-3 sigma) stimulates MMP-1 expression in dermal fibroblasts. J Invest Dermatol 2005;124:170-177.

23. Sarkhosh K, Tredget EE, Li Y, et al. Proliferation of peripheral blood mononuclear cells is suppressed by the indoleamine 2,3-dioxygenase expression of interferon-gamma-treated skin cells in a co-culture system. Wound Repair Regen 2003;11:337-345.

24. Wang J, Jiao $\mathrm{H}$, Stewart TL, et al. Accelerated wound healing in leukocyte-specific, protein 1-deficient mouse is associated with increased infiltration of leukocytes and fibrocytes. J Leukoc Biol 2007:82:1554-1563.

25. Wang JF, Jiao H, Stewart TL, et al. Fibrocytes from burn patients regulate the activities of fibroblasts. Wound Repair Regen 2007;15:113-121.

26. Yang L, Chan T, Demare J, et al. Healing of burn wounds in transgenic mice overexpressing transforming growth factor-beta 1 in the epidermis. Am J Pathol 2001;159:2147-2157.

27. Brigstock DR. The CCN family: a new stimulus package. J Endocrinol 2003;178:169-175.

28. Ghahary A, Shen YJ, Nedelec B, et al. Collagenase production is lower in post-burn hypertrophic scar fibroblasts than in normal fibroblasts and is reduced by insulin-like growth factor- 1 . J Invest Dermatol 1996;106:476-481.

29. Nagata K. Hsp47: a collagen-specific molecular chaperone. Trends Biochem Sci 1996;21:22-26.

30. Ishida $Y$, Kubota $H$, Yamamoto A, et al. Type I collagen in Hsp47-null cells is aggregated in endoplasmic reticulum and deficient in $\mathrm{N}$-propeptide processing and fibrillogenesis. Mol Biol Cell 2006;17:2346-2355.

31. Hinz B, Phan SH, Thannickal VJ, et al. The myofibroblast: one function, multiple origins. Am J Pathol 2007;170:1807-1816.

32. Hinz B. Formation and function of the myofibroblast during tissue repair. J Invest Dermatol 2007;127:526-537.

33. Darby IA, Hewitson TD. Fibroblast differentiation in wound healing and fibrosis. Int Rev Cytol 2007;257:143-179.

34. Scott PG, Dodd CM, Ghahary A, et al. Fibroblasts from post-burn hypertrophic scar tissue synthesize less decorin than normal dermal fibroblasts. Clin Sci (Lond) 1998;94:541-547.

35. Lebaron RG. Versican. Perspect Dev Neurobiol 1996;3:261-271.

36. Thomas GJ, Bayliss MT, Harper K, et al. Glomerular mesangial cells in vitro synthesize an aggregating proteoglycan immunologically related to versican. Biochem J 1994;302(Part 1):49-56.

37. Wang JF, Olson ME, Reno CR, et al. Molecular and cell biology of skin wound healing in a pig model. Connect Tissue Res 2000;41:195-211.

38. Bellemare J, Roberge CJ, Bergeron D, et al. Epidermis promotes dermal fibrosis: role in the pathogenesis of hypertrophic scars. J Pathol 2005;206:1-8. 
39. Yang L, Scott PG, Giuffre J, et al. Peripheral blood fibrocytes from burn patients: identification and quantification of fibrocytes in adherent cells cultured from peripheral blood mononuclear cells. Lab Invest 2002;82:1183-1192

40. Tredget EE, Yang L, Delehanty $M$, et al. Polarized Th2 cytokine production in patients with hypertrophic scar following thermal injury. J Interferon Cytokine Res 2006;26:179-189.

41. Prud'homme GJ, Piccirillo CA. The inhibitory effects of transforming growth factor-beta-1 (TGF-beta1) in autoimmune diseases. J Autoimmun 2000;14:23-42

42. Ghahary A, Shen YJ, Scott PG, et al. Expression of mRNA for transforming growth factor-beta 1 is reduced in hypertrophic scar and normal dermal fibroblasts following serial passage in vitro. J Invest Dermatol 1994;103:684-686.

43. Van Obberghen-Schilling E, Roche NS, Flanders KC, et al. Transforming growth factor beta 1 positively regulates its own expression in normal and transformed cells. J Biol Chem 1988;263:7741-7746.

44. Wang R, Ghahary A, Shen Q, et al. Hypertrophic scar tissues and fibroblasts produce more transforming growth factor-beta1 mRNA and protein than normal skin and cells. Wound Repair Regen 2000;8:128-137.

45. Wang JF, Olson ME, Reno CR, et al. The pig as a model for excisional skin wound healing: characterization of the molecular and cellular biology, and bacteriology of the healing process. Comp Med 2001;51:341-348.

46. Leask A, Abraham DJ. The role of connective tissue growth factor, a multifunctional matricellular protein, in fibroblast biology. Biochem Cell Biol 2003;81:355-363.

47. Wang JF, Olson ME, Ball DK, et al. Recombinant connective tissue growth factor modulates porcine skin fibroblast gene expression. Wound Repair Regen 2003;11:220-229.

48. Colwell AS, Phan TT, Kong W, et al. Hypertrophic scar fibroblasts have increased connective tissue growth factor expression after transforming growth factor-beta stimulation. Plast Reconstr Surg 2005;116:1387-1390; discussion 1391-1382.
49. Desmouliere A, Chaponnier C, Gabbiani G. Tissue repair contraction, and the myofibroblast. Wound Repair Regen 2005;13: 7-12.

50. Pinnell SR. Regulation of collagen synthesis. J Invest Dermatol 1982;79(Suppl 1):73s-76s.

51. Rudolph R. Wide spread scars, hypertrophic scars, and keloids. Clin Plast Surg 1987;14:253-260.

52. Cohen IK. Can collagen metabolism be controlled: theoretical considerations. J Trauma 1985;25:410-412.

53. Diegelmann RF, Cohen IK, McCoy BJ. Growth kinetics and collagen synthesis of normal skin, normal scar and keloid fibroblasts in vitro. J Cell Physiol 1979;98:341-346.

54. Scott PG, Dodd CM, Tredget EE, et al. Chemical characterization and quantification of proteoglycans in human post-burn hypertrophic and mature scars. Clin Sci (Lond) 1996;90:417-425.

55. Schneider EL, Mitsui Y, Au KS, et al. Tissue-specific differences in cultured human diploid fibroblasts. Exp Cell Res 1977;108:1-6.

56. Narayanan AS, Page RC. Serum modulates collagen types in human gingiva fibroblasts. FEBS Lett 1977;80:221-224.

57. Botstein GR, Sherer GK, Leroy EC. Fibroblast selection in scleroderma. An alternative model of fibrosis. Arthritis Rheum 1982;25: 189-195.

58. Borrello MA, Phipps RP. Differential Thy-1 expression by splenic fibroblasts defines functionally distinct subsets. Cell Immunol 1996;173:198-206.

59. Silvera MR, Phipps RP. Synthesis of interleukin-1 receptor antagonist by Thy-1+ and Thy-1 - murine lung fibroblast subsets. J Interferon Cytokine Res 1995;15:63-70.

60. Phipps RP, Penney DP, Keng P, et al. Characterization of two major populations of lung fibroblasts: distinguishing morphology and discordant display of Thy 1 and class II MHC. Am J Respir Cell Mol Biol 1989;1:65-74.

61. Mitsui Y, Schneider EL. Increased nuclear sizes in senescent human diploid fibroblast cultures. Exp Cell Res 1976;100:147-152.

62. Mitsui $Y$, Schneider EL. Characterization of fractionated human diploid fibroblast cell populations. Exp Cell Res 1976;103:23-30. 